Frankel, Carol Propper, Jenny Donovan, Alex Faulkner, and an anonymous referee for their comments and advice.

1 Frankel SJ. The epidemiology of indications. $\mathcal{I}$ Epidemiol Community Health 1991; 45:257-9.

2 Donaldson C, Mooney G. Needs assessment, priority setting, and contracts for health care: an economic view. $B M \mathcal{F}$ 1991;303:1529-30.

3 Drummond MF, Stoddart GL, Torrance GW. Methods for the economic evaluation of health care programmes. Oxford: Oxford University Press, 1987. Williams A. Economics of coronary artery bypass grafting. BMF 1985;291: 326-9.

5 Gudex C, Kind P. The QALY toolkit. York: Centre for Health Economics, 1988

6 Carr-Hill RA, Morris J. Current practice in obtaining the "Q" in QALYs: a cautionary note. BMF 1991;303:699-701

7 Bryan S, Parkin D, Donaldson C. Chiropody and the QALY: a case study in assigning categories of disability and distress to patients. Health Policy $1991 ; 18: 169-85$

8 Dixon AK, Southern JP, Teale A, Freer CEL, Hall LD, Williams A, et al. Magnetic resonance imaging of the head and spine: effective for the clinician or the patient? BMF 1991;302:79-82.

9 Gudex C, Williams A, Jourdan M, Mason R, Maynard J, O'Flynn R, et al. Prioritising waiting lists. Health Trends 1990;22:103-8.

10 Gudex C. OALYs and their use by the health service. York: Centre for Health Economics, 1986

11 Rosser R, Kind P. A scale of valuations of states of illness: is there a social consensus? Int $\mathcal{F}$ Epidemiol 1978;7:347-58.

12 Kind $\mathrm{P}$, Rosser R, Williams A. Valuation of quality of life: some psychometric evidence. In: Jones-Lee MW, ed. The value of life and safery. Amsterdam: North-Holland, 1982:159.

13 Eftekhar N. Charnley "low friction torque" arthroplasty. Clin Orthop

14 Central Statistical Office. Social trends 20. London: HMSO, 1990

14a Parsonage M, Neuburger H. Discounting and health benefits. Health Economics 1992;1:71-6.

15 Bernth-Petersen P. Cataract surgery. Outcome, assessments and epidemiological aspects. Acta Ophthalmol 1985;63:9-47.

16 Fowler FJ, Wennberg JE, Timothy RP, Barry MJ, Mulley AG, Hanley D. Symptom status and quality of life following prostatectomy. $\mathcal{F} A M A$ 1988;259:3018-22.

17 Barry MJ, Mulley AG, Fowler FJ, Wennberg JW. Watchful waiting vs immediate transurethral resection for symptomatic prostatism. The importance of patients' preferences. IAMA 1988;259:3010-7.

18 Woodward R, Boyarsky S, Barnett H. Discounting surgical benefits. Enucleation versus resection of the prostate. F Med Systems 1983;7:481-93.

Enucleation versus resection of the prostate. F Med Systems 1983;7:481-93.
Donovan J, Frankel S, Nanchahal K, Coast J, Williams M. Epidemiologically based needs assessment: prostatectomy for benign prostatic hypertrophy. Bristol: Health Care Evaluation Unit, 1991.

20 Chilton CP, Morgan RJ, England HR, Paris AMI, Blandy JP. A critical evaluation of the results of transurethral resection of the prostate. $\mathrm{Br} \mathcal{F}$ Urol 1978;50:542-6

21 Roos NP, Wennberg JE, Malenka DJ, Fisher ES, McPherson K, Anderson $\mathrm{TF}$, et al. Mortality and reoperation after open and transurethral resection of the prostate for benign prostatic hyperplasia. $N$ Engl f Med 1989;320: $1120-5$

22 Liang MH, Larson M, Thompson MS, Eaton H, McNamara E, Katz R, et al. Costs and outcomes in rheumatoid arthritis and osteoarthritis. Arthritis Rheum 1984;27:522-9.

23 Kaplan RM, Bush JW. Health-related quality of life measurement for evaluation research and policy analysis. Health Psychology 1981;1:61-80.

24 Paterson M. Assessment of treatment in rheumatoid arthritis. In: TeelingSmith G, ed. Measuring health: a practical approach. Chichester: John Wiley 1991:157.

25 Frankel SJ, Williams M, Nanchahal K, Coast J. Epidemiologically based needs assessment. Report 2: Total hip and total knee joint replacements. Bristol: Health Care Evaluation Unit, 1990.

26 Dobbs HS. Survivorship of total hip replacements. $\mathcal{F}$ Bone foint Surg $[\mathrm{Br}]$ 1980;62:168-73.

27 Knutson K, Lindstrand A, Lidgren L. Survival of knee arthroplasties. A nationwide multicentre investigation of 8000 cases. $\mathcal{F}$ Bone foint Surg [Br] 1986;68:795-803

28 Williams A. Applications in management. In: Teeling-Smith G, ed. Measuring health: a practical approach. Chichester: John Wiley, 1988:225.

29 McPherson K. Why do variations occur? In: Anderson TF, Mooney G, eds. The challenges of medical practice variations. London: Macmillan, 1990:16.

30 Ball AJ, Feneley RCL, Abrams PH. The natural history of untreated "prostatism". Brf Urol 1981;53:613-6.

(Accepted 12 May 1992

\title{
Oestrogen replacement after oophorectomy: comparison of patches and implants
}

\section{Harriet M Anderson, Shanti K Raju, Mary L Forsling, $M \mathrm{~J}$ Wheeler}

Premenopausal women undergoing prophylactic

Correspondence and requests for reprints to: Miss Raju.

$B M \mathcal{f} 1992 ; 305: 90-1$
Appendix

TABLE AI-Transformation used for prostatectomy, based on Fowler et al $^{16}$ and Rosser and Kind

\begin{tabular}{lcc}
\hline $\begin{array}{l}\text { Original study } \\
\text { scores }\end{array}$ & General health index & Rosser score \\
\hline & Disability & \\
$\begin{array}{l}\text { Activity index } \\
15\end{array}$ & & I \\
$12-14.99$ & & II \\
$9-11.99$ & Distress & III \\
& $15-18$ & \\
Symptom score & $12-14.99$ & A \\
Mild & $15-18$ & B \\
Mild & $12-14.99$ & B \\
Moderate & $15-18$ & C \\
Moderate & $12-14.99$ & C \\
Severe & & D \\
Severe & & \\
\hline
\end{tabular}

TABLE AII - Transformation used for total hip replacement, based on Eftekhar ${ }^{13}$ and Rosser and Kind

\begin{tabular}{|c|c|c|}
\hline $\begin{array}{l}\text { D'Aubigne and } \\
\text { Postel number }\end{array}$ & Description & $\begin{array}{l}\text { Rosser } \\
\text { score }\end{array}$ \\
\hline \multicolumn{3}{|c|}{ Disability } \\
\hline 6 & Normal in activity for age & I \\
\hline 5 & Walks without aid but has limp & II \\
\hline 4 & $\begin{array}{l}\text { Long distance walks possible but limited } \\
\text { without aids }\end{array}$ & III \\
\hline 3 & $\begin{array}{l}\text { Walking limited, but can stand for long } \\
\text { periods }\end{array}$ & IV \\
\hline 2 & $\begin{array}{l}\text { Duration and distance can walk limited with } \\
\text { and without walking aid }\end{array}$ & $\mathrm{V}$ \\
\hline 1 & Bedridden or can walk only a few yards & VI \\
\hline \multicolumn{3}{|c|}{ Distress } \\
\hline 6 & No pain & A \\
\hline 5 & Slight or intermittent, decreasing with activity & B \\
\hline 4 & $\begin{array}{l}\text { Present only after activity, disappears } \\
\text { quickly with rest }\end{array}$ & B \\
\hline 3 & Tolerable, permits limited activity & $\mathrm{C}$ \\
\hline 2 & $\begin{array}{l}\text { Severe on attempts to walk, prevents all } \\
\text { activity }\end{array}$ & $\mathrm{D}$ \\
\hline 1 & Severe, spontaneous & $\mathrm{D}$ \\
\hline
\end{tabular}

TABLE AII - Transformation used for total hip and total knee replacement, based on Liang et al ${ }^{22}$ and Rosser and Kind

\begin{tabular}{|c|c|c|c|c|c|c|}
\hline \multicolumn{6}{|c|}{ Original study scores } & \\
\hline & & & Disability & & & \\
\hline $\begin{array}{c}\text { Mobility } \\
5\end{array}$ & $\begin{array}{c}\text { Physical } \\
4\end{array}$ & $\begin{array}{c}\text { Social } \\
5\end{array}$ & $\begin{array}{c}\text { Weight } \\
0\end{array}$ & ${ }_{1}^{B U C P X}$ & $\begin{array}{c}\text { Average } \\
0.970-1\end{array}$ & I \\
\hline 5 & 4 & 4 & -0.061 & 0.939 & $0.939-0.970$ & II \\
\hline 5 & 4 & 3 & -0.061 & 0.939 & $0.909-0.939$ & III \\
\hline 5 & 3 & 2 & $-0 \cdot 121$ & 0.879 & $0.815-0.909$ & IV \\
\hline 4 & 3 & 1 & $-0 \cdot 248$ & 0.752 & $0.744-0.815$ & V \\
\hline 4 & 1 & 1 & $-0 \cdot 265$ & 0.735 & $0 \cdot 731-0.744$ & VI \\
\hline \multirow[t]{2}{*}{2} & 1 & 1 & -0.273 & 0.727 & $0.727-0.731$ & \\
\hline & & & Distress & & & \\
\hline
\end{tabular}

Symptom/problem complex score

$0 \cdot 0-2 \cdot 0$

$2 \cdot 0-2 \cdot 5$

$3 \cdot 0-4 \cdot 07$

*As weights for the points equating to Rosser disability II and III were identical, this number was taken to be the lower limit for II and the upper limit for III, rather than the midpoint (as for all other levels).

concentrations achieved and prevention of hot flushes.

\section{Subjects, methods, and results}

Premenopausal women undergoing bilateral oophorectomy were randomly allocated either oestradio patches $(0.05 \mathrm{mg}$ oestradiol $/ 24$ hours; $\mathrm{n}=12)$ or oestradiol implants $(50 \mathrm{mg}$ crystalline oestradiol pellet; $\mathrm{n}=16$ ) administered seven days after surgery. Blood samples for measurement of oestradiol, follicle stimulating hormone, and luteinising hormone concentrations were taken preoperatively, six days postoperatively, and after two and four months of treatment. Hormone concentrations were measured by routine radioimmunoassay. Oestradiol concentrations prevent menopausal symptoms. Oestrogen implants are effective in treating castrated women. ${ }^{1}$ The aim of this study was to compare the implant with the newer, transcutaneous system (the patch) in terms of hormone 
Department of Obstetrics and Gynaecology, United Medical and Dental Schools of Guy's and St Thomas's Hospitals, St Thomas's Campus, London SE1 7EH

$C$ Harriet $M$ Anderson, research fellow

Shanti K Raju, senior lecturer

Mary L Forsling, reader in

reproductive physiology

Department of Chemical Pathology

M J Wheeler, consultant clinical biochemist

Demographic data and serum hormone concentrations in patch and implant groups. Values are means (SE)

\begin{tabular}{|c|c|c|c|c|c|}
\hline & & $\begin{array}{l}\text { Patch group } \\
\quad(\mathrm{n}=12)\end{array}$ & $\begin{array}{l}\text { Implant group } \\
\quad(n=16)\end{array}$ & $\begin{array}{c}95 \% \text { Confidence } \\
\text { interval of difference } \\
\text { between means }\end{array}$ & $\mathrm{p}$ Value \\
\hline $\begin{array}{l}\text { Age (years) } \\
\text { Weight }(\mathrm{kg}) \\
\text { Height }(\mathrm{cm})\end{array}$ & $\left\{\begin{array}{l}\text { Preoperatively } \\
\text { Six days postoperatively }\end{array}\right.$ & $\begin{aligned} 45 \cdot 8 & (2 \cdot 0) \\
64 \cdot 1 & (2 \cdot 3) \\
162 & (1) \\
241 & (49) \\
63 & (3)\end{aligned}$ & $\begin{array}{c}44 \cdot 0(1 \cdot 7) \\
66 \cdot 1(1 \cdot 88) \\
164(2) \\
379(90) \\
\text { All }<60\end{array}$ & $\begin{array}{c}2 \cdot 7 \text { to } 6.4 \\
-8 \cdot 1 \text { to } 4 \cdot 0 \\
-0.08 \text { to } 0.03 \\
-371 \text { to } 94\end{array}$ & $\begin{array}{l}>0.01 \\
>0.1 \\
>0.1 \\
>0.1 \\
>0.1\end{array}$ \\
\hline Follicle stimulating hormone (IU/l) & $\left\{\begin{array}{l}\text { Preoperatively } \\
\text { Six days postoperatively }\end{array}\right.$ & $\begin{array}{r}8 \cdot 1(1 \cdot 9) \\
37 \cdot 3(4 \cdot 1)\end{array}$ & $\begin{array}{r}9 \cdot 6(1 \cdot 1) \\
47 \cdot 1(5 \cdot 6)\end{array}$ & $\begin{array}{r}-5 \cdot 8 \text { to } 2 \cdot 7 \\
-25 \cdot 1 \text { to } 5 \cdot 4\end{array}$ & $\begin{array}{l}>0 \cdot 1 \\
>0 \cdot 1\end{array}$ \\
\hline Luteinising hormone (IU/l) & $\left\{\begin{array}{l}\text { Preoperatively } \\
\text { Six days postoperatively }\end{array}\right.$ & $\begin{array}{r}6 \cdot 4(1 \cdot 0) \\
16 \cdot 3(2 \cdot 5)\end{array}$ & $\begin{array}{l}12 \cdot 0(2 \cdot 4) \\
22 \cdot 7(2 \cdot 6)\end{array}$ & $\begin{array}{l}-11 \cdot 7 \text { to } 0 \cdot 37 \\
-14 \cdot 0 \text { to } 1 \cdot 1\end{array}$ & $\begin{array}{l}>0 \cdot 1 \\
>0 \cdot 1\end{array}$ \\
\hline Oestradiol (pmol/l) & $\left\{\begin{array}{l}\text { After two months } \\
\text { After four months }\end{array}\right.$ & $\begin{array}{ll}178 & (31) \\
191 & (42)\end{array}$ & $\begin{array}{ll}226 & (22) \\
213 & (27)\end{array}$ & $\begin{array}{ll}-124 & \text { to } 30 \\
-121 & \text { to } 77\end{array}$ & $\begin{array}{l}>0 \cdot 1 \\
>0 \cdot 1\end{array}$ \\
\hline Follicle stimulating hormone (IU/l) & $\left\{\begin{array}{l}\text { After two months } \\
\text { After four months }\end{array}\right.$ & $\begin{array}{l}46 \cdot 7(4 \cdot 9) \\
53 \cdot 4(7 \cdot 9)\end{array}$ & $\begin{array}{l}22 \cdot 1(3 \cdot 6) \\
31 \cdot 6(6 \cdot 9)\end{array}$ & $\begin{aligned} 12 \cdot 3 & \text { to } 36.9 \\
0.3 & \text { to } 43.4\end{aligned}$ & $\begin{array}{r}<0.001 \\
0.047\end{array}$ \\
\hline Luteinising hormone (IU/l) & $\left\{\begin{array}{l}\text { After two months } \\
\text { After four months }\end{array}\right.$ & $\begin{array}{l}29 \cdot 6(3 \cdot 17) \\
32 \cdot 1(4 \cdot 9)\end{array}$ & $\begin{array}{l}16 \cdot 9(2 \cdot 1) \\
19 \cdot 2(3 \cdot 4)\end{array}$ & $\begin{array}{l}5 \cdot 2 \text { to } 20 \cdot 8 \\
1 \cdot 1 \text { to } 24 \cdot 8\end{array}$ & $\begin{array}{r}<0.001 \\
0.034\end{array}$ \\
\hline
\end{tabular}

in the postmenopausal range were expressed as $<60$ $\mathrm{pmol} / \mathrm{l}$. Presence of hot flushes was recorded preoperatively and after four months of treatment. Compliance with treatment was confirmed at interview. Change from preoperative hormone concentration to that six days postoperatively was analysed by McNemar's test for oestradiol (expressed as $<60$ $\mathrm{pmol} / \mathrm{l}$ or $>60 \mathrm{pmol} / \mathrm{l}$ ) and by paired Student's $t$ tests for follicle stimulating hormone and luteinising hormone. Unpaired Student's $t$ tests were performed for analyses between groups.

Mean age, weight, and height were not significantly different between the two groups (table). Preoperative hormone concentrations were within the premenopausal range and nei her preoperative nor postoperative concentration was significantly different between the groups. Six days after oophorectomy $89 \%$ of the subjects $(25 / 28)$ had an oestradiol concentration $<60$ $\mathrm{pmol} / \mathrm{l}(\mathrm{p}<0.001)$. Follicle stimulating hormone and luteinising hormone concentrations increased significantly by six days postoperatively (follicle stimulating hormone: mean change $33.9 \mathrm{IU} / 1$ (95\% confidence interval 26.3 to $41.6 \mathrm{IU} / \mathrm{l}), \mathrm{p}<0.001, \mathrm{df}=27, t=9 \cdot 0$; luteinising hormone: mean change $10 \cdot 3 \mathrm{IU} / 1(6 \cdot 1$ to $14 \cdot 6 \mathrm{IU} / \mathrm{l}), \mathrm{p}<0 \cdot 001, \mathrm{df}=27, t=5 \cdot 0$ ).

Mean oestradiol concentrations after two and four months of treatment did not differ significantly between the two groups. Mean follicle stimulating hormone and luteinising hormone concentrations were significantly higher in the patch group at two months $(\mathrm{p}<0.001)$ and four months $(p<0.05)$. Preoperatively none of the patients complained of hot flushes. After four months of treatment two of the 12 patients in the patch group and three of the 16 in the implant group complained of hot flushes.

\section{Comment}

Although recommended starting doses were selected in this study, the $0.05 \mathrm{mg}$ patch and $50 \mathrm{mg}$ implant were not equivalent in terms of hormone profiles; in terms of preventing hot flushes, however, they were equally effective. Hormone concentrations are not routinely measured in patients receiving oestrogen replacement, so this difference in hormone profiles would go undetected.

The two groups of women were equivalent in terms of hormone profile before starting oestrogen replacement. Concentrations of oestradiol, follicle stimulating hormone, and luteinising hormone in the implant group after two and four months of treatment were similar to those reported in other studies employing the same dose. ${ }^{1}$ Although the $0.05 \mathrm{mg}$ patch can suppress gonadotrophin release in women after a natural menopause ${ }^{2}$ it was ineffective in these women with surgical menopause. Kamel et al showed that even a $0.2 \mathrm{mg}$ patch was unable to sustain suppression of follicle stimulating hormone in oophorectomised women. ${ }^{3}$ The differences in gonadotrophin concentrations between the two groups may have resulted from the higher sustained oestradiol concentrations in the implant group, a finding also observed by Stanczyk et al. ${ }^{4}$ Oestrogen acts in a dose dependent manner to reduce gonadotrophins and prevent both the short term and long term sequelae of the menopause. ${ }^{5}$ Our results show that the intermediate doses of the patch and implant are not equivalent in terms of gonadotrophin suppression. This raises the question whether the oestradiol provided by the patch will be as effective as the implant in conferring the many long term benefits of oestrogen replacement to these oophorectomised women.

We thank the special trustees of St Thomas's Hospital and St Thomas's Baby Fund for financial help.

1 Thom MH, Collins WP, Studd JWW. Hormonal profiles in postmenopausal women after therapy with subcutaneous implants. Br $\mathcal{F}$ Obstet Gynaecol 1981;88:426-33.

2 Chetkowoski RJ, Meldrum DR, Steingold KA, Randle D, Lu JK, Eggena P, et al. Biologic effects of transdermal estradiol. N Engl f Med 1986;314: $1615-20$

3 Kamel EM, Maurer SA, Hochler MG, Hoffman DI, Rebar RW. Gonadotrophin dynamics in women receiving immediate or delayed transdermal estradiol after oophorectomy. Obstet Gynecol 1991; 78:98-102.

4 Stanczyk FZ Shoupe D, Nunez V, Marcias-Gonzales P, Vijod MA, Lobo AR. A randomised comparison of non oral estradiol delivery in postmenopausal A randomised comparison of non oral estradial

5 Selby PL, Peacock M. Dose dependent response of symptoms, pituitary, and bone to transdermal oestrogen in postmenopausal women. BMJ 1986;293: 1337-9.

(Accepted 22 May 1992)

\section{Correction}

\section{Is duplicate publishing on the increase?}

A typesetting error occurred in this short report by Tony Waldron (18 April, p 1029). The second paragraph of the methods and results section should begin: "In 1988, six of the 110 main articles ... had been published elsewhere." 